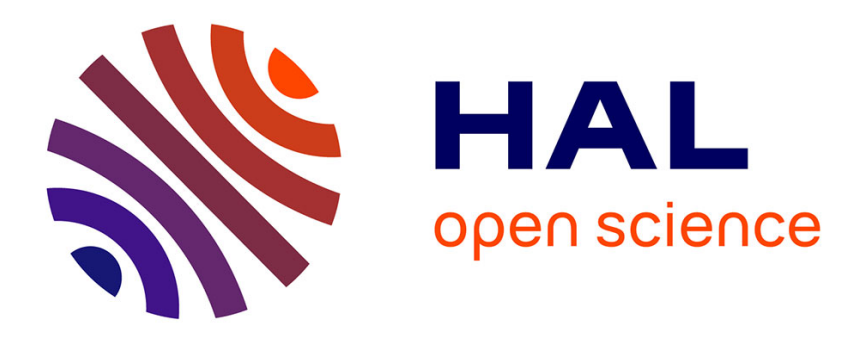

\title{
Queen production and instrumental insemination of Apis florea queens
}

\author{
Mananya Phiancharoen, Siriwat Wongsiri, H. Hepburn
}

\section{To cite this version:}

Mananya Phiancharoen, Siriwat Wongsiri, H. Hepburn. Queen production and instrumental insemination of Apis florea queens. Apidologie, 2011, 42 (3), pp.307-311. 10.1007/s13592-011-0068-y . hal-01003604

\section{HAL Id: hal-01003604 https://hal.science/hal-01003604}

Submitted on 1 Jan 2011

HAL is a multi-disciplinary open access archive for the deposit and dissemination of scientific research documents, whether they are published or not. The documents may come from teaching and research institutions in France or abroad, or from public or private research centers.
L'archive ouverte pluridisciplinaire HAL, est destinée au dépôt et à la diffusion de documents scientifiques de niveau recherche, publiés ou non, émanant des établissements d'enseignement et de recherche français ou étrangers, des laboratoires publics ou privés. 


\title{
Queen production and instrumental insemination of Apis florea queens
}

\author{
Mananya PHIANCHAROEN ${ }^{1}$, Siriwat WONGSIRI $^{2}$, H. Randall HePBURN ${ }^{3}$ \\ ${ }^{1}$ Ratchaburi Campus, King Mongkut's University of Technology Thonburi, Bangkok 10140, Thailand \\ ${ }^{2}$ School of Science, Mae Fah Luang University, Chiang Rai 57100, Thailand \\ ${ }^{3}$ Department of Zoology and Entomology, Rhodes University, 6140 Grahamstown, South Africa
}

Received 3 December 2009 - Revised 17 February 2010 - Accepted 27 May 2010

\begin{abstract}
Virgin queens of $A$. florea were produced in 10 queenless colonies yielding 106 queens with an average of $10.6 \pm 2.99$ queen cells per colony and a success rate of $65.23 \pm 0.14 \%$ virgin queens. Spermatozoa were collected directly from the seminal vesicles. Thirty queens were inseminated, each with a pool of about $3.12 \times 10^{6}$ spermatozoa derived from 8 drones. Six queens began to lay eggs 5 to 14 days after instrumental insemination. The mean number of spermatozoa reaching the spermatheca of inseminated queens was $0.74 \times$ $10^{6} \pm 0.45$ ( $=24 \%$ of the drone's spermatozoa) and the percentage of worker offspring was $100 \%$ in 5 queens and $83 \%$ in one queen. This method opens the possibility for new studies in genetics and selective breeding.
\end{abstract}

\section{Apis florea / queen production / instrumental insemination / spermatozoa / offspring}

\section{INTRODUCTION}

Although the history of attempts at the artificial insemination of honeybees can be traced back to the eighteenth century, it only became a practical breeding technique a little less than a century ago (Page et al. 2002). However, almost all published studies of instrumental insemination of honeybees have been directed at Apis mellifera. And, indeed, major advances in both genetics and selective breeding of $A$. mellifera have been accomplished over the last several decades. Turning to other species of honeybees, the techniques for the artificial insemination of Apis cerana were successfully developed by Woyke (1973, 1975). In addition there have been a few studies on heterospecific instrumental insemination

Corresponding author: M. Phiancharoen, manaya.phi@kmutt.ac.th Manuscript editor: Bernd Grünewald
(Koeniger et al. 1998; Phiancharoen et al. 2004; Ruttner and Maul 1983; Woyke 1993; Woyke et al. 2001) but none of these attempts resulted in viable hybrid offspring.

To date there have been no reports on attempts at instrumental insemination of the dwarf honeybees. This insemination is of special interest because the number of spermatozoa per drone $\left(0.38-0.44 \times 10^{6}\right.$ spermatozoa) is much lower than in all other honeybee species. On the other hand, the percentage of spermatozoa retained in the spermatheca is much higher (between 28 and $44 \%$ of $0.38-0.44 \times 10^{6}$ in Apis florea and between 66 and $74 \%$ of $0.13 \times 10^{6}$ in Apis andreniformis - Koeniger et al. 1989, 1990, 2000; Palmer and Oldroyd 2000) compared to less than $8 \%$ in all other species (Koeniger and Koeniger 2000). Furthermore, spermatozoa have already entered the spermatheca upon the return from the mating flight (Koeniger et al. 1989, 1990; Koeniger and Koeniger 2000) while in the cavity dwelling species, sperm is stored in the oviducts and spermatozoa only enters during the 
next 24 to $48 \mathrm{~h}$. The tip of the endophallus of the dwarf honey bees is pointed and smaller than that of $A$. mellifera and can probably deposit the sperm into or near the orifice of the spermathecal duct. Thus there are two difficulties to overcome- the small size of the queen and the need to deposit the sperm near the orifice of the spermathecal duct. The major difficulty here appears to be finding the correct depth at which to insert the syringe into the vagina or median oviduct without damaging tissues. There is also the possibility that the spermatozoa were discharged into the spermatheca and not the median oviduct (Koeniger et al. 1989, 1990; Koeniger and Koeniger 2000). Here we report the results of the first successful instrumental insemination of virgin queens of $A$. florea and their subsequent production of offspring.

\section{MATERIALS AND METHODS}

\subsection{Queen production}

Ten colonies of the red dwarf honeybee, A. florea, were collected in a nearby forest and moved to the Ratchaburi Campus, King Mongkut's University of Technology Thonburi, at Chom Bueng, Ratchaburi province, Thailand $\left(13^{\circ} 59^{\prime} \mathrm{N}, 99^{\circ} 51^{\prime} \mathrm{E}\right)$. Each colony was suspended from a branch of a tree at the edge of a copse. Queen production was induced simply by dequeening each colony and allowing them to construct emergency queen cells (Koeniger et al. 1989; Lekprayoon et al. 1989). The numbers of queen cells constructed in each colony were counted as were the number of virgin queens that successfully eclosed from the queen cells. When the cells were just being capped, they were cut from the combs and each placed in an individual small queen cage which was placed in an incubator at $34^{\circ} \mathrm{C}$ and relative humidity of $60-70 \%$ until adult emergence. The numbers of virgin queens that successfully eclosed from the queen cells were counted. The emerged virgin queens were caged and each queen cage was placed in a queenless colony. Between 5 and 10 days after emergence of the queens they were removed for instrumental insemination.

\subsection{Production of virgin queens in queenless colony}

There are two techniques for the production of virgin queens in queenless colonies.

The easiest method is simply to dequeen colonies and allow the workers to construct emergency queen cells and rear virgin queens. After the queen larvae are capped, they are cut from the comb, placed in individual cages and transferred to an incubator. When the queens emerge, they are simply reintroduced into the colonies which reared them.

However, if for some reason the first method is not practicable then combs with sealed brood are purchased from roadside bee hunters and, on returning to the apiary, they are placed very close to queenless colonies. Some workers from the queenless colony move on to this newly introduced comb and when sufficient numbers have done so to make the colony viable, that colony is moved and suspended in a different tree. These colonies are also used for the introduction of virgin queens.

\subsection{Semen collection and instrumental insemination of queens}

During the mating season drones were collected from the comb crown (the honey storage top part of the single comb) because such drones rising to the crown for flight between 12:00 and 16:30 are sexually mature (Koeniger and Wijayagunesekera 1976; Rinderer et al. 1993). Each drone of $A$. florea has only $0.38-0.44 \times 10^{6}$ spermatozoa (Koeniger et al. 1989; Phiancharoen et al. 2004) and thus far it has not been possible to successfully collect sperm from the everted endophallus as is the usual practice with A. mellifera. To overcome this problem, the technique of collecting semen from seminal vesicles was used (Koeniger et al. 1998; Phiancharoen et al. 2004). Semen collection from the seminal vesicles of drones and its preparation in buffer solution was performed using the methods of Phiancharoen et al. (2004).

For sperm counts, spermatozoa were collected from the seminal vesicles, thoroughly dispersed in a buffer solution and further diluted with distilled water to a volume of $5 \mathrm{~mL}$. The spermatozoa were counted with a Fuchs-Rosental haemocytometer using methods previously described (Koeniger et al. 1989). After- 
wards, A. florea queens were instrumentally inseminated at ages 5-10 days (Woyke and Jasinski 1976; Harbo 1986) with a total of about $3.12 \times 10^{6}$ spermatozoa collected from 8 drones and pooled to form a single ejaculate.

\subsection{Measuring queen size}

The lengths and widths of five queens of $A$. florea, A. cerana and $A$. mellifera were measured. The length was measured from the head to the tip of the abdomen while the width was measured from the first segment of the abdomen. These measurements were made to obtain an indication of size-related changes that it would be necessary to modify the queen-holder.

\subsection{Post-insemination}

After insemination the queens were returned in their cages to their nests for 1 day and then a candy plug was inserted in the cage to provide for the release of the queen. A few hours later the queens were moving freely on the combs and were allowed to oviposit for about 4 weeks to ensure continuity of oviposition as an indicator of successful insemination. During this period the brood comb was continually monitored until capped brood was present. The brood combs were examined 10 days later and number of offspring produced was counted. Then the queens were killed and dissected to count the number of spermatozoa in the spermathecae using a haemocytometer (Koeniger et al. 2000).

\section{RESULTS}

Using ten colonies of $A$. florea, a total of 106 queen cells with an average of 10.6 \pm 2.99 and a range of 6-16 per colony were produced. A total of 72 adult virgin queens were obtained with a mean of $7.2 \pm 3.01$ per colony and a range of 2-12 which was a yield of $65.23 \pm 0.14 \%$. Thirty individually caged queens were introduced into a queenless unit and were each inseminated with about $3.12 \times 10^{6}$ spermatozoa obtained from 8 drones. The number of spermatozoa in the seminal vesicles was $0.39 \times 10^{6} \pm$ $0.04(n=6)$ per drone. For reasons unknown to us, 24 queens died or disappeared after releas- ing them from the queen cage. All six queens started egg-laying from 5 to 14 days after insemination. Five queens produced $100 \%$ worker offspring, but one queen produced $83 \%$ worker offspring and $17 \%$ drone offspring. On dissection, this last queen was found to have only $0.26 \times 10^{6}$ in the spermatheca and was clearly not sufficiently well inseminated.

On average, the number of spermatozoa entering the spermatheca of an inseminated queen was $0.74 \times 10^{6} \pm 0.45$. On dissection of the instrumentally inseminated queens the median number of spermatozoa found in the spermatheca was $0.72 \times 10^{6}$. The distribution of spermatozoa had a maximum of $1.12 \times 10^{6}$ and a minimum of $0.26 \times 10^{6}$ spermatozoa (Figure 1).

The standard insemination apparatus of Schley was designed specifically for use on $A$. mellifera, which is larger than $A$. cerana and considerably larger than $A$. florea.

The respective lengths and widths $(\mathrm{mm})$ of these bees ( $n=5$ for each species) were $A$. mellifera $20.92 \pm 0.39$ and $5.08 \pm 0.25$, A. cerana $17.2 \pm 0.52$ and $4.86 \pm 0.42$, and A. florea $15.98 \pm$ 1.44 and $4.32 \pm 0.13$ (Table I). As the instrument stands, the holding tube of the queen holder is too long to hold an $A$. florea queen in position without her sliding down the tube. This difficulty was overcome by inserting a short length (either $3 \mathrm{~mm}$ or $5 \mathrm{~mm}$ depending on the size of the queen) of plastic tube within the queen

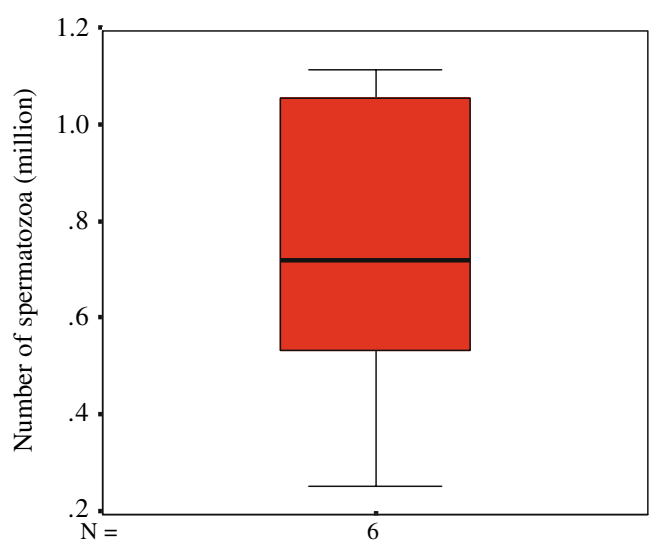

Figure 1. Number of spermatozoa reaching in spermatheca of inseminated queen. 
Table I. Queen body size of Apis species in length and width.

\begin{tabular}{lrr}
\hline Apis species & \multicolumn{1}{c}{$\begin{array}{l}\text { Body length } \\
(\mathrm{mm})\end{array}$} & \multicolumn{1}{l}{$\begin{array}{l}\text { Body width } \\
(\mathrm{mm})\end{array}$} \\
\hline A. mellifera $(n=5)$ & $20.92 \pm 0.39$ & $5.08 \pm 0.25$ \\
A. cerana $(n=5)$ & $17.2 \pm 0.52$ & $4.86 \pm 0.42$ \\
A. florea $(n=5)$ & $15.98 \pm 1.44$ & $4.32 \pm 0.13$ \\
\hline
\end{tabular}

holder. The internal diameter of the tip of the Schley queen holder is $4.5 \mathrm{~mm}$ and the hole in plastic tube insert which allows entry of $\mathrm{CO}_{2}$ was therefore reduced by $1 \mathrm{~mm}$.

\section{DISCUSSION}

This is the first report of the successful instrumental insemination of $A$. florea queens. That 72 A. florea queens were obtained from 10 colonies and emerged in an incubator opens up a new basis for research in several aspects. Likewise, the simplicity of splitting a colony into small units greatly facilitates experimentation. But instrumental insemination of $A$. florea queens proved to be extremely difficult even in the hands of a person very experienced in this technique with other species like A. mellifera and $A$. cerana largely because of the small size of $A$. florea queens (Phiancharoen et al. 2004). Indeed, using the standard Schley instrument, only 6 out of 30 queens were successfully inseminated instrumentally. The other queens that were inseminated died presumably because of internal injuries or because of rejection by the colony. The major difficulty here appears to be finding the correct depth at which to insert the syringe into the vagina or median oviduct without damaging tissues. There is also the possibility that the spermatozoa were discharged into the spermatheca and not the median oviduct (Koeniger et al. 1989, 1990; Koeniger and Koeniger 2000).

Semen collected from eight drones is within the range the mean paternity frequency of 8 drones (Oldroyd et al. 1995) and 11.16 \pm 5.0 drones later reported by Palmer and Oldroyd (2001). It has been reported that the percentage of spermatozoa that actually enter the spermatheca in natural mating is about 28.1\% (Palmer and Oldroyd 2000) and 44\% (Koeniger et al. 1989). In our instrumentally inseminated queens, the percentage of spermatozoa entering the spermatheca ranged from 8.33 to 35.90 . This proves that collecting sperm directly from the seminal vesicles with subsequent centrifugation is effective. These results open the possibilities for specific experimental studies in genetics and selective breeding.

Further work on artificial insemination of dwarf honeybees requires modification of the standard Schley apparatus. The queen holder as well as the dorsal sting hook must be adjusted to accommodate the small size of $A$. florea queens. Although positioning the queen in the tilted queen-holder was straight forward the addition of the small plastic tube in the queen holder is necessary. When the queen is in position, the queen holder is at an angle of about $30^{\circ}$ and more or less aligned with the long axis of the microsyringe. Opening the sting chamber with the dorsal sting hook proved difficult because the slot at the tip of the hook was too large to secure the sting in place. The ventral hook was just adequate but needs to be scaled down in size. A workable method for the instrumental insemination of $A$. florea queens has now been developed.

\section{ACKNOWLEDGEMENTS}

We gratefully thank the Thailand Research Fund (Grant MRG 4880008) and Commission on Higher Education for financial support.We also thank Prof. Dr. Nikolaus Koeniger and Dr. Gudrun Koeniger for their kind reviews of the manuscript.

Production de reines d'Apis florea et leur insémination artificielle.

Apis florea / production de reines / insémination artificielle / spermatozoïdes / descendance

Produktion und künstliche Besamung von Apis florea Königinnen.

Apis florea / Königinnenproduktion / künstliche Besamung / Spermatozoen / Nachwuchs 


\section{REFERENCES}

Harbo, J. (1986) Propagation and instrumental insemination, in: Rinderer Th.E. (Ed.), Bee Genetics and Breeding, Academic Press, Inc.

Koeniger, N., Koeniger, G. (2000) Reproductive isolation among species of the genus Apis. Apidologie 31, 313-319

Koeniger, N., Wijayagunesekera, H.N.P. (1976) Time of drone flight in the three Asian honeybee species (Apis cerana, Apis florea, Apis dorsata). J. Apic. Res. 15, 67-71

Koeniger, N., Koeniger, G., Wongsiri, S. (1989) Mating and sperm transfer in Apis florea. Apidologie 21, 413-418

Koeniger, G., Koeniger, N., Mardan, M., Punchihewa, R.W. K., Otis, G.W. (1990) Number of spermatozoa in queens and drones indicate multiple mating in Apis andreniformis and Apis dorsata. Apidologie 21, 281-286

Koeniger, G., Koeniger, N., Tingek, S., Kelitu, A (1998) A Preliminary report on hybrids between Apis cerana Fabricius, 1793 and Apis koschevnikovi v. Buttel- Reepen, 1906 produced by instrumental insemination. Apidologie 29, 462-463

Koeniger, G., Koeniger, N., Tingek, S., Kelitu, A. (2000) Mating flights and sperm transfer in the dwarf honey bee Apis andreniformis (Smith 1858). Apidologie 31, 301-311

Lekprayoon, C., Koeniger, N., Wongsiri, S. (1989) Queen production with Apis florea in Thailand, Proc. 1st Asia-Pac. Conf. Entomol, Chiang Mai, pp. 621-627.

Oldroyd, B.P., Smolenski, A.I.J., Cornuet, J.M., Wongsiri, S., Estoup, A., Rinderer, T.E., Crozier, R.H. (1995) Levels of polyandry and intracolonial relation-genetic relationship in Apis florea. Behav. Ecol. Sociobiol. 37, 329-335
Page, R.E. Jr., Gadau, J., Beye, M. (2002) The emergence of Hymenopteran Genetics. Genetics 160, 375-379

Palmer, K.A., Oldroyd, B.P. (2000) Evolution of multiple mating in the genus Apis. Apidologie 31, 235-248

Palmer, K.A., Oldroyd, B.P. (2001) Mating frequency in Apis florea revisited (Hymenoptera, Apidae). Insectes Soc. 48, 40-43

Phiancharoen, M., Wongsiri, S., Koeniger, N., Koeniger, G. (2004) Instrumental insemination of Apis mellifera queens with hetero-and conspecific spermatozoa results in different sperm survival. Apidologie 35, 503-511

Rinderer, T.E., Oldroyd, B.P., Wongsiri, S., Sylvester, H. A., De Guzman, L.I., Potichot, S., Sheppard, W.S., Buchman, S.L. (1993) Time of drone flight in four honeybees species in southeastern Thailand. J. Apic. Res. 32, 27-33

Ruttner, F., Maul, V. (1983) Experimental analysis of reproductive interspecies isolation of Apis mellifera $\mathrm{L}$. and Apis cerana Fabricius. Apidologie 14, 309-327

Woyke, J. (1973) Instrumental insemination of Apis cerana indica queen. J. Apic. Res. 12, 151-158

Woyke, J. (1975) Natural and instrumental insemination of Apis cerana indica in India. J. Apic. Res. 14, 153-159

Woyke, J. (1993) Rearing and instrumental insemination of Apis florea queens, in: Asian Apiculture, Proc.1st Int. Conf. on Asian honey bees and bee mites. Bangkok, Thailand, Wicwas Press Cheshire, CT, USA, pp. 206-210.

Woyke, J., Jasinski, Z. (1976) The influence of age on the result of instrumental insemination of honeybee queens. Apidologie 7, 301-306

Woyke, J., Wilde, J., Wilde, M. (2001) Apis dorsata drone flights, collection of semen from everted endophalli and instrumental insemination of queens. Apidologie 32, 407-416 